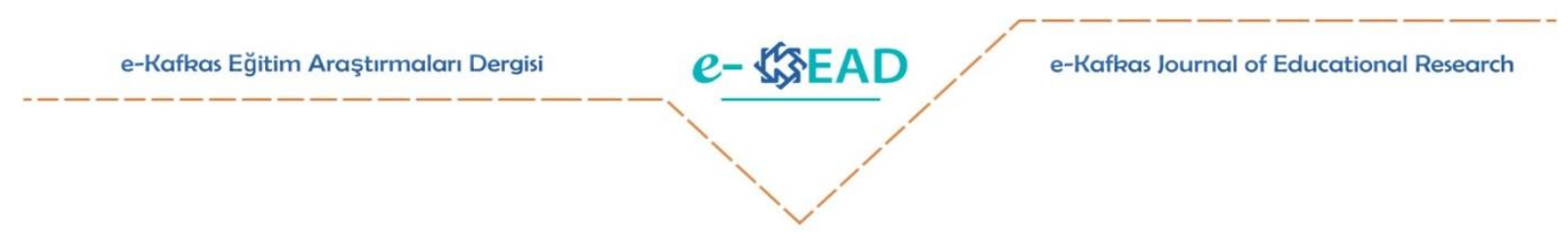

\title{
İlkokul Dördüncü Sınıf Öğrencilerinin Mutlulukla İlgili Düşüncelerinin Değerlendirilmesi: Nitel Bir Çalışma ${ }^{1}$
}

\author{
Faruk Caner YAM ${ }^{2}$ (D)
}

Atıf: Yam, F.C. (2020). İlkokul dördüncü sınıf öğrencilerinin mutlulukla ilgili düşüncelerinin değerlendirilmesi: Nitel bir çalışma. e- Kafkas Eğitim Araştırmaları Dergisi, 7, 262-281. doi:10.30900/kafkasegt.764370

Araştırma Makalesi

Geliş Tarihi:05.07.2020

Kabul Tarihi:15.09.2020

\section{$\ddot{O} z$}

$\mathrm{Bu}$ araştırmada ilkokul dördüncü sınıf öğrencilerinin mutluluk ile ilgili görüşlerinin incelenmesi amaçlanmıştır. Araştırmanın çalışma grubu $36 \mathrm{kız} \mathrm{ve} 42$ erkek olmak üzere toplam 78 öğrenciden oluşmaktadır. Araştırma nitel modellerden olgu bilim deseninde tasarlanmıştır. Çalışmanın verileri araştırmacı tarafından geliştirilmiş olan yarı yapılandırılmış açık uçlu sorular ile toplanmıştır. Araştırmada elde edilen nitel veriler içerik analizi yöntemi ile analiz edilmiştir. İçerik analizi sonrasında dört ana tema ve çeşitli kategoriler belirlenmiştir. Ortaya çıkan temalar mutluğun tanımı, birlikte olmaktan mutlu olunan kişiler, mutlu eden durumlar ve mutluluğun zihinsel temsilleri şeklinde isimlendirilmiştir. Yapılan içerik analizi sonucuna göre çocukların mutluluğu gülümseme, eğlenme, sevilme, hayal kurma ve sevdikleri ile bir arada olmak şeklinde tanımladıkları görülmüştür. Diğer açıdan çocukları mutlu eden durumların neler olduğu incelendiğinde bazı çocukların hediye almak, oyun oynamak, yüzmek gibi maddi şeylerden mutlu oldukları görülürken bazılarının ise sevmek, değer görmek ve sevilmek gibi manevi şeylerden mutlu oldukları görülmüştür. Ayrıca çocuklar anne, baba, dede, öğretmen ve arkadaşlarının yanlarında olmalarından dolayı mutlu olduklarını ifade etmişlerdir. Diğer açıdan mevcut araştırma kapsamında çocukların mutluluk ile ilgili metaforik algıları incelenmiştir. Çocukların mutluluk kavramı ile ilgili üretmiş oldukları metaforlar incelendiği zaman bazı çocukların mutluluğu olumlu yaşantılar ve doyum verici kavramlarla ilişkilendirdiği ancak bazı çocukların mutlulukla ilgili olumsuz metaforlar ürettikleri görülmüştür. Sonuç olarak, çocukların mutluluk kavramına ilişkin çeşitli zihinsel imgelere sahip oldukları saptanmıştır. Elde edilen sonuçlar alanyazın ışığında tartışılmıştır.

Anahtar Sözcükler: İlkokul öğrencisi, metafor, mutluluk, nitel araştırma.

\begin{abstract}
In this study, it was aimed to examine the opinions of students about happiness in the fourth grade of primary school. The study group of the research consists of 78 students, 36 girls and 42 boys. The research was designed in a qualitative model and the data were collected by a form consisting of semi-structured open-ended questions. Qualitative data obtained in the study were analyzed by content analysis method. After the content analysis, four main themes and various categories were identified. According to the results of the content analysis, it was seen that children define happiness as smile, fun, love, dream and being together with their loved ones. On the other hand, when the situations that make children happy are examined, it is seen that some children are happy with material things like buying gifts, playing, swimming, while others are happy with spiritual things such as loving, valued and loved. In addition, the children stated that they were happy that the parents, grandparents, teachers and friends were with them. On the other hand, within the scope of the current research, metaphorical perceptions of children about happiness were examined. When the metaphors produced by children about the concept of happiness are examined, it is seen that some children associate happiness with positive experiences and satisfying concepts, but some children produce negative metaphors about happiness. As a result, it was found that children have formed a wide variety of mental images related to the concept of happiness. The results obtained are discussed in the light of the literature.
\end{abstract}

Keywords: Primary school student, metaphor, happiness qualitative research.

\footnotetext{
${ }^{1}$ Bu çalışma 12-14 Nisan 2019 tarihinde Üsküdar Üniversitesi bünyesinde gerçekleştirilen 3. Avrasya Pozitif Psikoloji Kongresi'nde sunulan sözlü bildirinin genişletilmiş halidir.

${ }^{2}$ Öğretim Görevlisi, farukcaneryam@ @otmail.com, Gaziosmanpaşa Üniversitesi, Adalet Meslek Yüksekokulu, Türkiye
} 


\section{Giriş}

Mutluluk, bireylerin hayatta ulaşmayı ve elde etmeyi arzuladıkları şeylere ulaşmaktan dolayı hissetmiş oldukları duygu olarak ifade edilmektedir (TDK, 2020). Diğer bir ifade ile mutluluk bireylerin olumlu duyguları olumsuz duygulara kiyasla daha fazla hissetmesidir (Doğan, 2013). Bu kavram pozitif psikoloji ve bu alanda çalışma yapan araştırmaların en popüler konularından birisi olmuştur. Pozitif psikoloji ise mutluluğu öznel iyi oluş kavramı ile ifade etmektedir (Diener, 1984). Öznel iyi oluş, bireylerin olumlu duyguları daha sık, olumsuz duyguları daha az hissetmeleri ve yüksek düzeyde yaşam doyumu elde etmeleri olarak ifade edilmektedir (Diener, 1984; Myers ve Diener 1995). Diğer bir ifadeyle öznel iyi oluş kişinin kendi yaşamını bilişsel ve duygusal olarak değerlendirmesi olarak tanımlanmaktadır (Diener ve Lucas, 1999). Bu alanda çalışma yapan pozitif psikoloji araştırmacıları mutluluğun ne olduğu, bireylerin nasıl mutluluk oldukları, mutluluk düzeyleri üzerinde etkili olan faktörlerin neler olduğu ve bunu yanı sıra bireylerin mutluluk düzeylerinin nasıl arttırılabileceği konularında çalışmalar yürütmüşlerdir (Deiner, 2000; Deiner ve Seligman, 2002; Carr, 2016; Rff, 1989; Seligman ve Csikszentmihalyi, 2000; Seligman, 2012). Ancak mutlulukla ilgili yapılan araştırmalar ve geliştirilen teorilerin çoğunlukla yetişkin örneklem gruplarından elde edilen verilere dayandığı ifade edilmektedir (Sabalova, Birdsey, Stuart-Hamilton ve Cousins, 2020). Yetişkinlerin mutluluklarıyla ilgili alanyazında çeşitli araştırmalar ve teoriler bulunmasına karşın çocukların mutluluk kavramına ilişkin bakış açılarını değerlendiren çalışmaların sınırlı olduğu belirtilmektedir (Chaplin, 2009; Park ve Wang, 2019).

Mutluluk, çocukların gelişimlerine katkı sağlayan en temel duygulardan birisidir (Hong, Ra ve Jang, 2015). Ayrıca mutluluk duygusu çocuklarda küçük yaşlardan itibaren gelişmekte ve çocuklar bebeklik dönemlerinden itibaren mutluluğu hissetmeye ve anlamaya başlamaktadırlar (Honig ve Brophy, 1996; Harter 1983; Lewis ve Michalson, 1983). Bu nedenle çocukların mutluluk düzeyleri sağlıklı gelişim geçirmeleri üzerinde oldukça etkili olmaktadır (Bird ve Markle, 2012). Bunun yanı sıra çocukların mutluluk düzeyleri duygusal ve bilişsel gelişimlerinin temel belirleyicisi olarak görülmektedir. (Kantarcıoğlu, 1998). Yapılan araştırmalarda mutluluk düzeyleri yüksek olan çocuk ve ergenlerin daha az psikolojik sorunlar yaşadıkları (Richter, Gilbert ve McEvan, 2009), stresle baş edebilme becerini daha aktif kullandıkları (Benson, 2014; Pretlow, 2011), olumlu arkadaşlık ilişkileri geliştirebildikleri (Aypay ve Eryılmaz, 2011) ve okul doyumlarının daha yüksek olduğu (Huebner, Suldo, Valois, Darne ve Zullig, 2004) sonuçlarına ulaşılmıştır. Diğer açıdan mutluluğun, çocukları kayg1 ve stresli yaşam olaylarına karşı koruma görevi gördüğü ifade edilmektedir (Lyubomirsky, 2001; Mahon ve Yarcheski, 2002). Bundan dolayı alanyazında çocukların mutluluk düzeylerini arttıracak çalışmaların ve eğitim programlarının düzenlenmesinin önemli olduğu belirtilmektedir (Engels, Aelterman, Petegem ve Schepens, 2004; Seligman, 2002; Seligman, Ernst, Gillham, Reivich ve Linkins, 2009). Çocukların mutluluk düzeylerinin desteklenebilmesi için ise onların mutluluk kavramını nasıl algıladıklarının bilinmesi gerekmektedir. $\mathrm{Bu}$ sayede mutlulukla ilgili çocuklara sunulacak olan desteğin niteliği ve içeriğinin belirlemesi daha kolay olacaktır (Ben-Arieh, 2006). Çünkü çocukların mutluluk algılarının değerlendirildiği araştırmalarda, çoğunlukla ebeveynlerinin görüşlerine başvurulmuş ve çocukların mutluluk kavramına bakış açıları ebeveynlerinin gözünden anlaşılmaya çalışılmıştır (Hong, Kim ve Jeun, 2016; Parkı ve Wang, 2019). Bu nedenle mutlulukla ilgili yapılacak her türlü çalışmada çocukların bakış açılarının dikkate alınmasının önemli olduğu vurgulanmaktadır. (Fattore, Mason ve Watson, 2007).

Çocukların mutluluk düzeylerinin yüksek olması, onların çevrelerine yönelik olumlu bir bakış açısı geliştirmelerine ve çevreleri ile etkili bir iletişim kurmalarına yardımcı olmaktadır (Demiriz ve Ulutaş, 2016). Çocukların mutluluk düzeylerinde meydana gelen azalmalar onların arkadaş ilişkilerinde bozulmalara, okul başarılarında düşüşlere, yalnızlık düzeylerinde artışlara ve istenmeyen davranışları sergilemelerine neden olabilmektedir (Yucel ve Yuan, 2015). Diğer açıdan çocukların mutluluk duygusuyla ilgili ilk deneyimleri onların hayata dair olumlu bir bakış açısı kazanmalarına destek olmaktadır. Çünkü yapılan araştırmalarda mutlu insanların çevresindeki olayları yorumlama, değerlendirme ve tepkide bulunma tarzlarının mutlu olmayan insanlara göre daha yapıcı ve sağlıklı olduğunu saptanmıştır (Lu, 1995; Lyubomirsky, King ve Diener, 2005; Lyubomirsky, 2001). Bu sonuçlar bireylerin mutluluk düzeylerinin bütün yaşam alanları üzerinde etkili olabildiğine işaret etmektedir (Carr, 2016). 
Mutluluk kavramı ve bireylerin mutlulukları üzerinde etkili olan faktörlerin önemli araştırma konusu yapıldığ düzeylerini etkileyen faktörlerin incelenmesi onların bütün gelişim alanlarının daha sağlıklı bir şekilde desteklenmesi açısından oldukça önemlidir. Çünkü sahip olunan mutluluk düzeyi bütün gelişim dönemlerindeki bireylerin yaşam kaliteleri üzerinde etkili olabilmektedir. $\mathrm{Bu}$ nedenle mutluluğun çocuklar tarafindan nasıl algılandığı ve onların yaşamlarında nasıl bir yere sahip olduğu önemli bir araştırma konusudur (Fattore, vd., 2009). Alanyazında mutlulukla ilgili yapılan araştırmaların genellikle yetişkin merkezli olduğu ve çocukların mutlulukları ile ilgili çalışmaların ihmal edildiği ifade edilmektedir (Chaplin, 2009; Sabolova, Birdsey, Hamilton ve Cousins, 2020). Bu nedenle yetişkin bireylerle ilgili mutluluk tanımları ve teorileri geliştirilmesine rağmen çocuklar için hali hazırda bir mutluluk tanımı ve teorisi bulunmadığı söylenmektedir (Sabalova, Birdsey, StuartHamilton ve Cousins, 2020). Araştırmacılar çocukların mutlulukla ilgili bir bakış açısına sahip olduklarını bilmelerine rağmen onların mutluluklarıyla ilgili yaptıkları çalışmalarında sıklıkla ebeveynlerinin görüşlerine başvurmaktadırlar (Ben-Arieh, 2006; Hwang, Kim ve Tak, 2013; Hong, Ra ve Jang, 2015). Ancak çocukların mutlulukla ilgili görülüşlerinin ebeveynleri üzerinde incelenmesinin güvenilir sonuçlar vermeyeceği ve bu nedenle çocukların mutluluk algılarının değerlendirilmesinde doğrudan kendi görüşlerine başvurulması gerektiği ifade edilmektedir (Fattore, vd., 2009; Hong, vd., 2015). Ayrıca çocukların mutluluklarıyla ilgili yapılacak araştırmalarda öncelikli olarak çocukları mutlu eden durumların neler olduğuna odaklanılmasının önemli olduğu vurgulanmaktadır (Park ve Paterson, 2006). Yukarıda açıklanan gerekçelerden dolayı mevcut araştırmada ilkokul dördüncü sınıf öğrencilerinin mutluluk ile ilgili düşüncelerini incelemek ve ilgili alanyazına katkı sağlamak amaçlanmıştır. $\mathrm{Bu}$ amaç doğrultusunda çocukların mutluluk tanımları, kendilerini mutlu eden durumların neler olduğu, birlikte olmaktan dolayı mutlu oldukları kişilerin kimler olduğu ve mutluluk kavramına ilişkin metaforik algıları incelenmiştir. Araştırma sonucunda elde edilen bulguların ilgili alanyazına, araştırmacılara, ebeveynlere ve politika üreticilerine önemli katkılar sunacağı düşünülmektedir.

\section{Yöntem}

$\mathrm{Bu}$ araştırma ilkokul dördüncü sınıf öğrencilerinin mutluluk ile ilgili düşüncelerinin değerlendirildiği nitel araştırma modellerinde olgu bilim deseninde bir çalışmadır. Olgu bilimsel desen, ayrıntılı bilgi sahibi olunmayan konularla ilgili katılımcıların görüş̧ ve deneyimlerinin incelendiği bir araştırma modelidir (Yıldırım ve Şimşek, 2006). Nitel araştırmalarda asıl amaç araştırma konusunu derinlemesine incelemektir (Creswell, 2014; Chone, Manion ve Morrison, 2013). Ancak nitel araştırma desenlerinin belirli avantaj ve dezavantajları bulunmaktadır. Daha detaylı bilgiye ulaşılması, verilerin doğal ortamda toplanabilmesi gibi avantajları bulunmakla birlikte tekrar edilebilirlik, geçerlilik ve güvenirliğin test edilmesindeki zorluklar gibi dezavantajları bulunmaktadır (Balc1, 2007; Böke, 2007). Bu nedenlerden dolayı nitel araştırmada geçerlilik ve güvenirlik için gerekli olan koşulların sağlanması nitel araştırmalar için büyük önem taşımaktadır (Yıldırım ve Şimşek, 2013). Ayrıca bu araştırmada çocukların mutluluk kavramına yönelik sahip oldukları zihinsel temsillerini ortaya çıarmak ve incelemek için metafor yöntemine başvurulmuştur (Amundson, 2011; Jensen, 2006). Çünkü bireyler metafor kullanımı sayesinde birbiriyle ilişkisi olmayan iki kavramı bir araya getirerek, ifade etmekte zorlandıkları soyut ifadeleri somutlaştırma firsatı elde etmektedirler (Midgley, Trimmer ve Davies, 2014). Ayrıca bireyler metafor kullanarak somut yaşantılarından hareketle soyut bir konuyu daha anlaş1lır bir şekilde ifade edebilmektedirler (Lakoff ve Johnson, 2005). Bu nedenle bu araştırmada açık uçlu soruların yanında, çocukların mutlulukla ilgili soyut olan zihinsel imgelerini benzetim aracıllı̆̆ıla ifade etmelerini kolaylaştıracağ ${ }_{1}$ düşünüldüğünden metafor tekniği kullanılmıştır.

\section{Çalıșma Grubu}

Araştırmanın çalışma grubu amaçlı örneklem yöntemlerinden olan kolay örnekleme yöntemi ile belirlenmiştir. Kolay örnekleme yöntemi araştırmacının zaman, emek ve maliyet konusunda tasarruf sağlamak maksadıyla araştırmanın amacına uygun veriler toplayabileceğini ve ulaşılabilirlik açısından daha kolay olduğunu düşündüğü bir grubu örneklem olarak belirlemesidir (Yıldırım ve Şimşek, 2013). Bu araştırmanın çalışma grubunu ise Orta Karadeniz Bölgesi'nde bulunan bir ilkokuldaki dördüncü sınıfa devam eden ve araştırmaya gönüllü olarak katılan 36 kız (\% 46.2) ve 42 
erkek (\%53.8) öğrenciden oluşmaktadır. Araştırmaya katılan öğrencilerden 6'sı tek çocuk (\%7.7), 34'ü 2 kardeş (\%43.6), 26'sı 3 kardeş (33.3), 8'i 4 kardeş (\%10.3) ve 4’ü 5 kardeştir (\%5.1).

\section{Veri Toplama Araci}

Araştırmanın veri toplama aracı çalışmanın amacına uygun olarak belirlenmiş dört tane açık uçlu sorudan oluşmaktadır. Bu sorular hazırlanmadan önce mutluluk kavramıyla ilgili kuramsal alanyazın (Diener, 1984; Myers ve Diener 1995; Ryff, 1989; Seligman, 2012) ve alanyazında çocukların mutluluk algılarıyla ilgili yapılmış araştırmalar (Hong,vd., 2015; Hong, Kim ve Jeun, 2016; Ocak-Karabey ve Güzeldere-Aydın, 2017; Thoilliez,, 2011; Ünüvar, Çalışandemir, Tagay ve Amini, 2015) incelenmiştir. Daha sonra oluşturulan dört soru araştırmanın amacına ve kuramsal yapıya uygun olup olmadığının değerlendirilmesi için sınıf öğretmenliği bölümü ile psikolojik danışmanlık ve rehberlik bölümündeki birer alan uzmanına gönderilmiş, dönüt sağlamaları istenmiştir. Ayrıca veri toplama aracının dördüncü sınıf öğrencilerinin gelişim dönemlerine uygun olup olmadığının incelenmesi için dördüncü sınıf okutmakta olan iki sınıf öğretmeninin görüşlerine başvurulmuştur. $\mathrm{Bu}$ dönütlerden sonra dördüncü sınıfa devam eden yedi öğrenci üzerinde oluşturulan veri toplama aracının pilot uygulama gerçekleştirilmiş ve veri toplama aracının öğrenciler tarafından anlaşılabilir olduğu görülmüştür. Bu süreçlerden elde edilen geri bildirimler 1şığında veri toplama aracı aşağıdaki gibi düzenlenmiştir:

1-Sence mutluluk nedir?

2-Hangi durumlarda mutlu olursun? Seni mutlu eden şeyler nelerdir? (hediye almak, sevdiğin yemeği yemek, ailenle gezmek gibi)

3-Hayatında seni mutlu eden ve yanında olmaktan mutlu olduğun kişi veya kişiler kimlerdir?

4-Mutluluğu bir şeye benzetmek istersen; Mutluluk.............gibidir/benzer.

Çünkü..........................

\section{Veri Toplama Süreci}

Veri toplama aracına son şekli verildikten sonra çalışma grubunun bulunduğu okula gidilmiş, okul yönetimi ile gerekli görüşmeler yapılmış, veri toplama aracının uygulanacağı sınıflarda bulunan çocuklara araştırmanın içeriği ve amacı açıklanmıştır. Daha sonra araştırmaya katılmak isteyen ögrencilere araştırma veli onam formu dağıtılmış ve öncelikli olarak çocukların ebeveynlerinden onay alınma işlemi gerçekleştirilmiştir. Bu çalışmadan bir hafta sonra araştırma yapılacak okula tekrar gidilmiş, velisi tarafından araştırmaya katılmasına izin verilen gönüllü öğrencilerle çalışma sürdürülmüştür. Veri toplama aracı uygulanırken çocuklardan ilk üç soruyu cevapladıktan sonra beklemeleri istenmiş, sınıftaki bütün öğrenciler metafor sorusuna gediklerinde araştırmacı "Evet çocuklar dördüncü soruyu şu şekilde cevaplamanı beklenmektedir. Mutluluğu bir şeye benzetmek isteseydiniz, sevdiğiniz bir nesne, bir kişsi, bir bitki, yapmaktan hoşlandiğınız bir şey veya herhangi başka bir şey de olabilir neye benzetmek isterdiniz. Örneğin mutluluk şeker gibidir. Çünkü onun gibi insana güzel tatlar yaşatır gibi siz olsaydınız bu örnekteki gibi mutluğu neye benzetmek isterseniz yazıp sonrada neden buna benzettiğiniz yazmanız benim için yeterli olacaktır" şeklinde yönerge verilerek veri toplama sürecini sürdürmüştür. Veri toplama sürecinde hiçbir öğrenci kendi rızası dışında araştırmaya katılması konusunda zorlanmamıştır. Bütün süreç gönüllük esasına göre yürütülmüş, öğrencilerin veri toplama aracını doldurmaları için geniş bir zaman dilimi tanınmıştır

\section{Verilerin Analizi}

Elde edilen veriler içerik analizi yöntemi ile incelenmiştir. İçerik analizi, toplanan yazılı veya sözlü verilerin araştırmanın problemlerine cevap verecek şekilde sınıflandırılması, özetlenmesi ve verilerin çeşitli temalara göre kategorilere ayrılması sürecidir (Arık, 1998). İçerik analizinin asıl amacı toplanan verileri belirli kategoriler altında kodlayarak, bunların sıklık düzeyini belirlemektir (Simon,1985). Bu kapsamda araştırma sürecinde öğrencilerden toplanan veriler, mutluluk kavramı ile ilgili kuramsal çerçeveye ve araştırmanın amacına uygun bir şekilde kodlanmıştır. Daha sonra ortaya çıkan kodlar kuramsal yapı dikkate alınarak belirlenen temalar altında toplanmış ve frekansları çıkarılmıştır. Her kodun ve temanın almış olduğu frekanslar gözden geçirilerek ilişkili olan temalar ve kategoriler yeniden gözden geçirilmiştir. 


\section{Araştırmanın Geçerlik ve Güvenirliği}

Nitel araştırmalarda geçerlilik ve güvenirliğin sağlanması için araştırma yöntemi, veri toplama süreci ve örneklem grubunun belirlenmesiyle ilgili detaylı açıklamalara yer verilmesi önerilmektedir (Marrow, 2005). Bunun için çalışmanın veri toplama aracı, veri toplama süreci, örneklem gurubu, veri toplanan mekân, analiz yöntemleri ve araştırmanın diğer bütün aşamaları şeffaf bir şekilde açıklanmıştır. Diğer açıdan nitel araştırmalarda kapsam geçerliliğinin sağlanması için veri toplama aracının araştırmanın amacına uygun şekilde belirlenmesi gerektiği söylenmektedir (Eisenhart ve Hove, 1992). Bu doğrultuda veri toplama aracı oluşturulmadan önce mutluluk kavramı ile ilgili kuramsal bilgiler incelemiştir. Ayrıca alanyazında çocukların mutluluk algılarının değerlendirildiği araştırmalar incelenenerek veri toplama aracının soruları belirlenmiştir. Veri toplama aracı için belirlenen soruların araştırmanın amacına uygun olup olmadığının belirlenmesi için üniversitede rehberlik ve psikolojik danışmanlık bölümü ve sınıf öğretmenliği bölümünde çalışan uzmanlardan yardım alınmıştır. Çünkü nitel araştırmalarda veri toplama aracının geliştirilmesi ve analiz süreçlerinde elde edilen verilerin geçerliliğinin sınanması için uzman görüşü (Yıldırım ve Şimsek, 2013), değerlendirmeci geçerliği (Maxwell, 1992) ve meslektaş değerlendirilmesine (Guba ve Lincoln,1986) gibi yöntemlerin kullanılmasının önemli olduğu söylenmektedir. Yine bu nedenle veri toplama aracının dördüncü sınıf öğrencilerinin gelişim dönemlerine uygun olup olmadığının incelenmesi için dördüncü sınıf okutmakta olan iki sınıf öğretmeninin görüşlerine başvurulmuştur.

Nitel araştırmalarda elde edilen verilerin nasıl toplandığ şekilde yansıtılması nitel çalışmaların güvenirliği ile ilgili unsurlar olduğu belirtilmektedir (Merriam, 2009). Bunun için araştırma sürecinde verilerin nasıl toplandığ1, kod ve temaların nasıl belirlendiği detaylı bir şekilde açıklanmıştır. Diğer açıdan elde edilen sonuçların tutarlı bir şekilde sunulması için ise katılımcılardan elde edilen görüşlerle ilgili alıntılara yer verilmesi önerilmektedir (Yıldırım ve Şimşek, 2013). Bundan dolayı çalışmada ortaya çıkan kategori ve temalarla ilgili öğrenci görüşlerinden alıntılara yer verilerek elde edilen sonuçlar desteklenmeye çalışılmıştır. Ayrıca içerik analizi sonucunda ortaya çıkan kategoriler ve temalar psikolojik danışma ve rehberlik alanında bir uzmana gönderilmiş, tema ve kategorileri "uygun"- "uygun değil" şeklinde değerlendirerek dönüt vermesi istenmiştir. Ardından değerlendiriciden gelen dönütleri ile araştırmacının görüşleri arasındaki tutarlılık, Miles ve Huberman'nın (1994) "güvenirlik= görüş birliği/(görüş birliği + görüş ayrıllğı)x100 formülü” ile hesaplanmış ve sonucun yeterli düzeyde $(52 /(52+8)$ X $100=\% 87)$ olduğu görülmüştür.

\section{Etik Kurallara Uygunluk}

Araştırmanın veri toplama sürecine başlamadan önce öğrenciler velileri araştırma konusunda bilgilendirilmiş ve onayları alınmıştır. Ardından veri toplama aracının uygulanacağı örneklem grubuna araştırmanın amacı açıklanmıştır. Veriler gönüllülük esasına göre tarafsız bir şekilde toplanmış, yönlendirmeden ve zorlamadan uzak durulmuştur. Diğer açıdan öğrencilerin cümlelerinden alıntılar yer verilikken kişisel bilgilerinin gizliliğine dikkat edilmiştir. Bunun için öğrenciler 1'den 78' kadar numaralandırılarak öğrenci görüşleri ile ilgili alıntılar erkek öğrenciler için "EÖ1, EÖ2, EÖ3..." kız öğrenciler için ise “ KÖ1, KÖ2, KÖ3...” şeklinde temsil edilerek sunulmuştur. Bu araştırmanın bir kısmı 2019 yılı Nisan ayında uluslararası bir kongrede sözlü bildiri olarak sunulmuştur. Ancak 2020 yılında değişen etik kurallar gereği araştırmanın genişletilmiş sürümünün gerçekleştirilebilmesi için Ondokuz Mayıs Üniversitesi Sosyal ve Beşeri Bilimler Etik Kurulu'ndan (Karar No: 2020/3-178) etik kurul onayı alınarak araştırma sürdürülmüştür.

\section{Bulgular}

Araştırmada katılımcılara yönetilen sorulara verilen cevaplardan elde edilen bulgular, alanyazına ve çalışmanın amacına uygun olarak belirlenen kategori ve temalar altında toplanarak sunulmuştur. Diğer açıdan çocukların mutlulukla ilgili üretmiş oldukları metaforlar Deiner ve arkadaşları (1999) tarafından tanımlanan öznel iyi oluş (mutluluk) kavramı temele alınarak içerik analizi yapılmış, elde edilen sonuçlar yaşam doyumu, olumlu duygular ve olumsuz duygular başlıkları altında temalandırılarak sunulmuştur.

Çocukların "Sence mutluluk nedir?" sorusuna yönelik vermiş oldukları yanıtlara ilişkin bulgular Tablo 1' de sunulmuştur. 
Tablo 1.

Çocukların Mutluk Kavramının Tanımıyla İlgili Görüş̧eri

\begin{tabular}{lcccc} 
& \multicolumn{2}{c}{ Cinsiyet } & Toplam & Yüzde \\
\cline { 2 - 5 } Kategoriler & Kiz (f) & Erkek(f) & $(\mathbf{f})$ & $(\%)$ \\
\hline Gülümse & 8 & 11 & 19 & 19.79 \\
Sevinme ve sevinç hissetme (istedikleri & 8 & 8 & 16 & 16.67 \\
bir şey olduğunda zaman ) & & & 15 & 15.63 \\
Sevdiklerimle bir arada olmak (aile, & 9 & 6 & & 13.55 \\
arkadaş gibi) & & & 13 & 11.44 \\
Sevmek/sevilmek & 6 & 7 & 11 & 10.42 \\
İnsandaki güzel bir duygu & 3 & 8 & 10 & 6.25 \\
Eğlenmek & 4 & 6 & 6 & 4.17 \\
Hayattaki maddi ve manevi her şey & 4 & 2 & 4 & 2.08 \\
Heyecan hissetme & 1 & 3 & 2 & 100 \\
Hayal kurmak & 2 & - & 96 & \\
Toplam (f) & 45 & 51 & & \\
\end{tabular}

Tablo 1'de görüldüğü üzere çocuklara sorulan 'Sence mutluluk nedir?' soruna yönelik çocukların verdikleri cevaplar incelendiğinde en çok "gülümse" (n=19; \%19.79), "istedikleri bir şeyin olmasından dolayl hissedilen sevinme/sevinç" $(\mathrm{n}=16)$ ve "sevdikleri ile bir arada olmak" $(\mathrm{n}=15)$ durumlarına vurgu yaptıkları görülmüştür. Bunların yanı sıra çocukların mutluluk tanımları içerisinde sevmek/sevilmek $(\mathrm{n}=13)$, insandaki güzel bir duygu $(\mathrm{n}=11)$ ve eğlenmek $(\mathrm{n}=10)$ gibi durumların da yer aldığı görülmektedir. Aşağıda çocukların bu tema ile ilgili söyledikleriyle ilgili örnek cümlelere yer verilmiştir.

KÖ4: Bence mutluluk güzel olan maddi ve manevi hey şey mutluluk, aile, arkadaş, kendimizle ilgili özel bir gün, bir hediye gibi güzel olan birçok şey insanı mutlu eder, bu yüzden bence maddi ve manevi anlamda her şey mutluluktur.

EÖ8: Herhangi bir şeyin benim yüzümü güldürdüğü zaman duyulan duygu.

KÖ9: Bence mutluluk her şeydir. Çünkü insan mutlu olunca başka hiçbir şey istemiyor. Mesela fakir olup mutlu olmak mı yoksa zengin olup mutsuz olmak mı gibi ben olsam fakir olup mutlu olmayı seçerdim.

EÖ10: Mutluluk birisine herhangi bir şey yaptığımızda, o kişinin bize göstermiş olduğu sevgi ve saygıdan dolayı hissetmiş olduğumuz duygudur.

EÖ5: Bence mutluluk insanların istediklerinin iyi sonucu doğrultusunda duyduğu his, duygu.

KÖ24: Bence mutluluk hayattaki en önemli maddedir yani benim için arkadaşlarımla ve akrabalarımla olduğum zamanki hissettiğim şey.

KÖ39: Mutluluk bir insanın bir kişiye karşı gösterdiği samimilik hissi veya bir kişinin diğer bir kişinin içini iyi hislerle doldurmasıdır.

EÖ72: Mutluluk çok eğlendiğimiz zaman oluşan duygudur ve en güzel duygumuzdur.

Çocuklara yöneltilen "Hangi durumlarda mutlu olursun/seni mutlu eden şeyler nelerdir?" sorusuna yönelik vermiş oldukları yanıtlara ilişkin bulgular Tablo 2'de sunulmuştur. 
Tablo 2.

Çocukların Mutlu Oldukları Durumlarla İlgili Görüş̧leri

\begin{tabular}{lcccc}
\hline \multirow{2}{*}{ Kategoriler } & \multicolumn{2}{c}{ Cinsiyet } & Toplam & Yüzde \\
\cline { 2 - 5 } & Kız (f) & $\begin{array}{c}\text { Erkek } \\
(\mathbf{f})\end{array}$ & $\mathbf{( f )}$ & $(\boldsymbol{\%})$ \\
\hline $\begin{array}{l}\text { Aile ile vakit } \\
\text { geçirmek(Anne/Baba/Kardeş) }\end{array}$ & 27 & 21 & 48 & 30.19 \\
Hediye verilmesi & & & & \\
Oyun oynamak/arkadaşlarla vakit & 19 & 21 & 40 & 25.16 \\
geçirmek & 9 & 18 & 27 & 16.98 \\
Gezmek/seyahat etmek & 11 & 7 & 18 & 11.32 \\
Deniz veya havuza girmek/yüzmek & 2 & 5 & 7 & 4.40 \\
Bir şeyler yemek & 3 & 3 & 6 & 3.77 \\
Başarılı olmak/yüksek not almak & 3 & 2 & 5 & 3.14 \\
Kitap okumak & 2 & 2 & 4 & 2.52 \\
Alşveriş yapmak & 2 & - & 2 & 1.26 \\
Eğitim almak & 2 & - & 2 & 1.16 \\
Toplam (f) & 80 & 79 & 159 & 100 \\
\hline
\end{tabular}

Tablo 2'de görüldüğü üzere çocukların 'Hangi durumlarda mutlu olursunuz?' sorusuna verdikleri cevaplar içerisinde en çok "aile ile birlikte vakit geçirmek ( $\mathrm{n}=48 ; \% 30.19)$, "hediye almak" $(\mathrm{n}=40)$ ve "oyun oynamak/arkadaşlarla vakit geçirmek" $(\mathrm{n}=27)$ konularına vurgu yapmışlardır. Bunların haricinde çocuklar "gezmek/seyahat etmek" $(\mathrm{n}=18)$, "deniz veya havuza girmek/yüzmek" ( $\mathrm{n}=$ 7), "bir şeyler yemek" ( $\mathrm{n}=6)$ "başarll olmak" $(\mathrm{n}=5)$, "kitap okumak" $(\mathrm{n}=4)$ ve "okul/eğitim almak" $(\mathrm{n}=2)$ ve "alış veriş yapmak" ( $\mathrm{n}=2)$ gibi durumlardan mutlu olduklarını ifade etmişlerdir. Aşağıda çocukların söylediklerine ilişkin örnek cümleler verilmiştir.

Tablo 3.

Çocukların Yanlarında Olmalarından Dolayı Mutlu Oldukları Kişilerle İlgili Görüşleri

\begin{tabular}{lcccc}
\hline \multirow{2}{*}{ Kategoriler } & \multicolumn{2}{c}{ Cinsiyet } & Toplam & Yüzde \\
\cline { 2 - 5 } & Kiz (f) & Erkek (f) & (f) & $(\%)$ \\
\hline Baba & 38 & 36 & 74 & 25.25 \\
Anne & 37 & 35 & 72 & 24.58 \\
Arkadaş & 19 & 23 & 42 & 14.33 \\
Kardeş (abi, abla, kardeş) & 14 & 19 & 33 & 11.26 \\
Akrabalar (amca, day1, teyze gibi) & 15 & 10 & 25 & 8.53 \\
Büyükbaba & 7 & 9 & 16 & 5.47 \\
Büyükanne & 9 & 6 & 15 & 5.13 \\
Öğretmen & 7 & 7 & 14 & 4.77 \\
Kendim & 2 & - & 2 & 0.68 \\
Toplam (f) & 148 & 145 & 293 & 100 \\
\hline
\end{tabular}

Tablo 3'te görüldüğü üzere çocukların "Yanında olmasından dolayı mutlu olduğun kişiler kimlerdir?" sorusuna verdikleri yanttlar incelendiğinde en çok "baba" ( $\mathrm{n}=74 ; \% 25.25)$, "anne" $(\mathrm{n}=72)$, "arkadaş" $(\mathrm{n}=42)$ ve "kardeş" $(\mathrm{n}=33)$ cevaplarını vermişlerdir. Ayrıca çocuklar yanlarında olmasından dolayı mutlu oldukları kişilere "akrabalar" ( $\mathrm{n}=25)$, "büyükbaba" (n=16), "büyükanne" $(n=15)$, "öğretmen" $(n=14)$ gibi cevaplar da vermişlerdir. Aşağıda bu temaya ilişkin çocukların ifadelerine yer verilmiştir.

EÖ2: Beni hayatımda özellikle mutlu eden kişiler annem, babam, kardeşlerim ve arkadaşlarımdır.

KÖ4: Annem, babam, arkadaşlarım, tüm akrabalarım ve ögretmenlerim. Başkalarına yardım eden insanların yanımda olması beni çok mutlu eder.

EÖ10: Anne, baba, dede, abla, teyze, ögretmenim, Eren ve Serhan.

KÖ11: Hayatımda beni mutlu eden kişiler dedem, babam, annem, ablam, kardeşim, anneannem, teyzem ve dayım.

KÖ15: Hayatımda beni mutlu eden kişiler ilk olarak aile bireylerim, akrabalarım, en yakın arkadaşlarım, ögretmenim ve kedim. 
EÖ18: Benim hayatımda beni mutlu eden kişiler annem, babam ve abimdir. Onları görünce çok mutlu oluyorum çünkü.

KÖ22: Benim hayatımda beni mutlu eden kişiler abim .....

EÖ25: Beni mutlu eden kişilerden en başta E. olmak üzere tüm arkadaşlarım

\section{KÖ52: Annem, arkadaşlarım ve ögretmenim}

Çocukların mutluluk kavramına ilişkin zihinsel imgeleri metafor tekniğiyle incelenmiştir. Bunun için çocuklara "Mutluluk........gibidir/ benzer. Çünkü..........." sorusu yöneltilmiştir. Daha sonra çocukların verdikleri cevaplar incelenmiş ve mantıklı bir bağlantı kurulmadığı tespit edilen on iki katılımcı analiz dışı bırakılmıştır. 64 katılımcı mutlulukla ilgili 24 farklı metafor üretmiştir. Ortaya çıkan metaforlar Tablo 4'te sunulmuştur.

Tablo 4.

Çocukların Mutluluk İle İlgili Üretmiş Oldukları Metaforlar

\begin{tabular}{lccclccc}
\hline & \multicolumn{2}{c}{ Cinsiyet } & & & \multicolumn{2}{c}{ Cinsiyet } & \\
\cline { 2 - 3 } Metaforlar & Kiz(f) & Erkek(f) & Toplam(f) & Metaforlar & Kız (f) & Erkek(f) & Toplam(f) \\
\hline 1.Gökyüzü & 2 & - & 2 & 14.Gülen Yüz & - & 3 & 3 \\
2.İnsan & - & 2 & 2 & 15.Huzur & 1 & 2 & 3 \\
3.Eğlence & 1 & 1 & 2 & 16.Sevgi & 1 & 1 & 2 \\
4.Aile & 5 & 4 & 9 & 17.Deniz & 1 & 2 & 3 \\
5.Çiçek & 3 & 4 & 7 & 18.Pasta & 1 & - & 1 \\
6.Pamuk & 2 & 3 & 5 & 19.Su & 4 & - & 4 \\
7.Uçmak & 1 & 1 & 2 & 20.Harita & - & 1 & 1 \\
8.Hayat & 2 & - & 2 & 21.Araba & - & 1 & 1 \\
9.Kitap & - & 1 & 1 & 22.Kurşun Kalem & - & 1 & 1 \\
10.Balon & 1 & - & 1 & 23.Arkadaş & - & 1 & 1 \\
11.Hediye & 1 & - & 1 & 24.Kuş & - & 1 & 1 \\
12.Rüzgâr & 1 & - & 1 & 25.Bulut & - & 2 & 2 \\
13. Hayal & 1 & - & 1 & 26.Şeker & 4 & 1 & 5 \\
Toplam(f) & 20 & 16 & 36 & Toplam (f) & 12 & 16 & 28 \\
\hline
\end{tabular}

Mutluluk pozitif psikoloji ekolünde öznel iyi oluş olarak kavramsallaştırılmakta ve kişinin kendi yaşamını bilişsel ve duyuşsal olarak değerlendirmesi ve bu değerlendirmeden elde etmiş olduğu memnuniyet düzeyi olarak tanımlanmaktadır (Diener, 1984). Bu nedenle çocukların Tablo 4'teki mutluluk ile ilgili üretmiş oldukları metaforlar Deiner ve arkadaşlarının (1999) tanımlamış oldukları öznel iyi oluş kavramının, bilişsel bileşeni olan yaşam doyumu, duyuşsal bileşenleri olan olumlu ve olumsuz duygular başlıkları altında temalandırılmıştır.

Çocukların mutlukla ilgili üretmiş oldukları metaforlardan yaşam doyumu temasına ait bulgular Tablo 5'te sunulmuştur.

Tablo 5.

Yaşam Doyumu Teması

\begin{tabular}{lcccc}
\hline Kategoriler & \multicolumn{2}{c}{ Cinsiyet } & Toplam & Yüzde \\
\cline { 2 - 5 } & Kiz (f) & Erkek (f) & $(\mathbf{f})$ & $(\boldsymbol{\%})$ \\
\hline Aile & 5 & 4 & 9 & 47.37 \\
Huzur & 1 & 2 & 3 & 15.79 \\
Insan & - & 2 & 2 & 10.53 \\
Hayat & 2 & - & 2 & 10.53 \\
Kitap & - & 1 & 1 & 5.26 \\
Harita & - & 1 & 1 & 5.26 \\
Arkadaş & - & 1 & 1 & 5.26 \\
Toplam (f) & 8 & 11 & 19 & 100 \\
& & & & \\
\hline
\end{tabular}

Öznel iyi oluşun yaşam doyumu bileşenini sosyal ilişkiler, sağlık, akademik yaşam, aile ilişkilerinin kalitesi, yaşamdan duyulan memnuniyet gibi faktörlerden oluşturmaktadır. Tablo 5 
incelendiğinde çocukların yaşam doyumu temasında en çok "aile" (n=9) metaforunu ürettikleri görülmüştür. Bunun yanı sıra çocukların bu tema altında "huzur" (n=2), "insan ve hayat" (n=2), "kitap, harita ve arkadaş" ( $\mathrm{n}=1)$ şeklinde metaforlar da kullanmışlardır. Aşağıda çocukların bu temaya ilişkin ifadelerinden örneklere yer verilmiştir.

EÖ2: Mutluluk bir insan gibidir. Çünkü insanlar bizi mutlu ederler.

KÖ4: Mutluluk aile gibidir. Çünkü her zaman yanında olmasını istersin.

KÖ9: Mutluluk hayat gibidir. Çünkü mutluluk her şeyin içinde olmalıdır.

EÖ10: Mutluluk kitap gibidir. Çünkü kitap gibi bizi içine alır ve hayal dünyasında gezdirir.

EÖ13: Mutluluk anne, baba gibidir. Çünkü onlar gibi her zaman bizimle olmalıdır.

KÖ31: Mutluluk ailem gibidir. Çünkü mutluluk onlarla olduğum zaman olan şeydi.

KÖ43: Mutluluk arkadaş edinmek gibidir. Çünkü arkadaşllk gibi güzel bir şeydir.

EÖ62: Mutluluk harita gibidir. Çünkü bize lazım olan her şey içinde vardır.

Deiner ve arkadaşları (1999) bireylerin olumlu duyguları yaşanma sıklıkları yükseldikçe öznel iyi oluş düzeylerinin yükseldiğini belirtmişledir. Buradan hareketle çocukların mutlulukla ilgili olumlu yaşantılar ve durumlarla ilişkilendirdikleri metaforları öznel iyi oluş kavramının olumlu duygularyaşantılar bileşeni altında toplanmış ve Tablo 6'da sunulmuştur.

Tablo 6.

Olumlu Duygular-Yaşantılar Teması

\begin{tabular}{lcccc}
\hline Kategoriler & \multicolumn{2}{c}{ Cinsiyet } & Toplam & Yüzde \\
\cline { 2 - 5 } & Kız (f) & Erkek (f) & (f) & $(\%)$ \\
\hline Çiçek & 4 & 4 & 8 & 18.60 \\
Pamuk & 2 & 3 & 5 & 11.63 \\
Şeker & 4 & 1 & 5 & 11.63 \\
Su & 4 & - & 4 & 9.30 \\
Gülen Yüz & - & 3 & 3 & 6.97 \\
Deniz & 1 & 2 & 3 & 6.97 \\
Uçmak & 1 & 1 & 2 & 4.65 \\
Bulut & - & 2 & 2 & 4.65 \\
Eğlence & 1 & 1 & 2 & 4.65 \\
Gökyüzü & 2 & - & 2 & 4.65 \\
Sevgi & 1 & 1 & 2 & 2.33 \\
Pasta & 1 & - & 1 & 2.33 \\
Beyaz Balon & 1 & - & 1 & 2.33 \\
Hediye & 1 & - & 1 & 2.33 \\
Araba & - & 1 & 1 & 2.33 \\
Kuş & - & 1 & 1 & \\
Toplam (f) & 23 & 20 & 43 & \\
& & & & \\
\hline
\end{tabular}

Tablo 6'da görüldüğü üzere olumlu duygular-yaşantılar temasında 43 öğrenci 16 farklı metafor üretmiştir. Tabloda da görüleceği üzere çocuklar mutluluğun (öznel iyi oluş) kaynağı olan ve yaşamasından hoşnutluk hissedilen durumlara vurgu yapmışlar ve en çok "çiçek" ( $\mathrm{n}=7)$, pamuk $(\mathrm{n}=5)$, "şeker" ( $\mathrm{n}=5)$ ve "su" $(\mathrm{n}=4)$ metaforlarını kullanmışlardır. Bunu yanı sıra Tablo 6'ya bakıldığı zaman çocukların mutluluk kavramının olumlu yaşantılar temasıyla ilgili birçok metafor ürettikleri görülmektedir. Aşağıda çocukların bu temaya ilişkin ifadelerinden örneklere yer verilmiştir.

KÖ6: Mutluluk çiçek gibidir. Çünkü onun gibi güzel kokar.

EÖ7: Mutluluk pamuk gibidir. Çünkü onun gibi yumuşak ve güzel bir şeydir.

KÖ11: Mutluluk beyaz bir balona benzer. Çünkü beyaz balon gibi çok temiz bir duygudur.

KÖ15: Mutluluk hediye gibidir. Çünkü bir kişiden hediye almak kadar güzeldir 


\section{EÖ27: Mutluluk uçan bir şey gibidir. Çünkü insanı rahat ve huzurlu hissettirir}

EÖ28: Mutluluk bulut gibidir. Çünkü onun gibi temiz ve yumuşaktır

EÖ30: Mutluluk gülen yüze benzer. Çünkü mutlu olduğunuz zaman hep gülümseriz

EÖ38: Mutluluk deniz gibidir. Çünkü onun gibi güzeldir ve insanı rahatlatır

\section{KÖ41: Mutluluk gökyüzü gibidir. Çünkü insanın gökyüzüne bakıca huzur dolması gibidir}

KÖ53: Mutluluk pasta gibidir. Çünkü pasta yediğim zaman mutlu olurum ve benim mutlu olduğumu görenler de çok mutlu olur.

KÖ59: Mutluluk su gibidir. Çünkü onun gibi saftır.

EÖ63: Mutluluk şeker gibidir. Çünkü hayatı tatlandırır.

EÖ72: Mutluluk araba gibidir. Çünkü seni istediğin yere sürükler.

Deiner ve arkadaşları (1999) öznel iyi oluşun duyusşal boyutunda olumsuz duygular-yaşantılar bileşenin de yer aldığını ve bireylerin yaşamış oldukları olumsuz olayların ve hissetmiş oldukları olumsuz duyguların bireylerin öznel iyi oluşlarında azalmalara neden olacağını belirtmişledir. $\mathrm{Bu}$ nedenle çocukların mutlulukla ilgili üretmiş oldukları olumsuz metaforlar, olumsuz duygularyaşantılar teması altında toplanarak Tablo 7'de sunulmuştur.

Tablo 7.

Olumsuz Duygular-Yaşantılar Teması

\begin{tabular}{|c|c|c|c|c|}
\hline \multirow[t]{2}{*}{ Kategoriler } & \multicolumn{2}{|c|}{ Cinsiyet } & \multirow{2}{*}{$\begin{array}{c}\text { Toplam } \\
\text { (f) }\end{array}$} & \multirow{2}{*}{$\begin{array}{c}\text { Yüzde } \\
(\%)\end{array}$} \\
\hline & Kız (f) & Erkek (f) & & \\
\hline Kurşun Kalem & - & 1 & 1 & 33.33 \\
\hline Hayal & 1 & - & 1 & 33.33 \\
\hline Rüzgâr & 1 & - & 1 & 33.33 \\
\hline Toplam (f) & 2 & 1 & 3 & 100 \\
\hline
\end{tabular}

Tablo 7'de görüldüğü üzere çocukların olumsuz duygular-yaşantılar teması, üzüntü, hayal kırıklığı gibi durumları barındırmaktadır. Çocuklar bu tema altında toplam 2 kız ve 1 erkek katılımcı olmak 3adet metafor üretilmiştir. Aşağıda çocukların bu temaya ilişkin ifadelerine yer verilmiştir.

KÖ18: Mutluluk hayal gibidir. Çünkü bir anda kaybolur.

KÖ24: Mutluluk rüzgar gibidir. Çünkü üzüldüğ̈̈m zaman hemen uçup gider.

EÖ76: Mutluluk kurşun kalem gibidir. Çünkü hemen silinir.

\section{Tartışma, Sonuç ve Öneriler}

Araştırmada ilkokul dördüncü sınıf öğrencilerinin mutlulukla ilgili düşüncelerinin değerlendirilmesi amaçlanmıştır. Bu doğrultuda ilk olarak çocuklara "Sence mutluluk nedir?" sorusu yönetilmiş ve çocukların bu soruya gülümseme, sevme-sevinç, sevdiklerimle bir arada olma, sevmek ve sevilmek, hayal kurmak gibi yanıtlar verdikleri görülmüştür. Alanyazında bu konuyla ilgili yapılmış olan bazı çalışmaların mevcut araştırma bulgusunu desteklediği görülmektedir. Tobin'in (2014) çocuklarla gerçekleştirmiş olduğu araştırmada çocukların mutluluk kavramını tanımlarken zorlanmalarına rağmen mutluluğu aile ile birlikte olmak, olumlu duygular, gülümseme ve komedi gibi deneyimlerle ilişkilendirdikleri sonucuna ulaşmıştır. Yine çocukların mutluluk algılarını değerlendirildiği başka bir nitel araştırmada (Hong, Ra ve Jang, 2015) çocukların mutluluğu iyi hissetmek, sevinç duymak, sevmek ve eğlenmek olarak nitelendirdikleri rapor edilmiştir. Yapılan bir diğer nitel çalışmada (Giacomoni, Souza ve Hutz, 2014) ilkokul çocuklarına "Mutlu olmak ne demektir?" sorusu yönetilmiş ve çocukların gülmek, sevinç duymak, yardım etmek, paylaşmak şeklinde cevaplar verdikleri görülmüştür. Ünüvar ve arkadaşlarının (2015) 4-6 yaş arası çocuklar üzerinde yapmış oldukları nitel bir araştırmalarında çocuklara "Sence mutluluk nedir?" şeklinde bir soru yöneltilmiş ve çocuklardan eğlenmek, beslemek, güvende olmak gibi cevaplar alınmıştır. Bu 
konuda yapılan diğer çalışmalarda da benzer sonuçların elde edildiği görülmektedir (Büyükkucak, 2014; Hong, vd., 2016; Lansdown, 2005; Miller, 2009; Park1 ve Wang, 2019; Sabolova, vd., 2020). Alanyazındaki araştırma sonuçlarının mevcut araştırma bulgusunu desteklediği ifade edilebilir. Diğer açıdan çocukların "Sence mutluluk nedir?" sorusuna verdikleri cevaplara bakıldığ zaman, mutluluk tanımları içerisinde maddi doyum sağlayıcı öğelerden daha çok manevi doyum sağlayıcı öğelere önem verdikleri söylenebilir. Ayrıca mevcut araştırma bulgusu ve alanyazındaki diğer araştırmaların sonuçlarının benzer olması farklı kültürdeki çocukların mutluluk tanımlarının da benzer olduğunu düşündürebilir. Diğer bir ifade ile hangi kültürden ve coğrafyadan olursa olsun çocukların genellikle birbirine benzer mutluluk tanımlamalarına sahip olduğu söylenebilir. Bu benzerliğe mutluluğun farklı kültürdeki insanlar tarafından deneyimlenen evrensel bir nitelik taşımasının neden olduğu söylenebilir. Deiner ve Lucas (2004) bireylerin farklı kültürlerde yetişmelerine rağmen benzer düzeyde mutluluk elde etme çabalarının olduğunu ifade etmesi bu yorumu destekler niteliktedir. Ancak çocukların mutluluk kavramına ilişkin algılarının daha iyi anlaşılabilmesi için yetiştikleri kültürün, yaşadıkları coğrafi bölgenin, sosyo-ekonomik koşullarının etkili olacağı göz önüne alınarak değerlendirmenin daha doğru olacağı ifade edilebilir. Diğer açıdan çocukların mutluluk kavramına ilişkin çoğunlukla olumlu tanımlamalar yaptığı görülmüştür. Elde edilen mevcut araştırma bulgusunun mutluluk ile ilgili geliştirilen teorik yapıyla da örtüştüğü söylenebilir. Çünkü Deiner'in (1984) öznel iyi oluş modeli, Seligman'ın (2012) PERMA modeli ve Ryff '1n (1989) psikolojik iyi oluş modeli incelendiği zaman bu modellerin en önemli bileşenlerinden birisinin bireyin sahip olduğu olumlu duygular ve yaşantılar olduğu görülmektedir. Ayrıca alanyazında bireylerin olumlu yaşantıları yükseldikçe mutluluk düzeylerinin de yükseleceği belirtilmektedir (Lyubomirsky; 2001; Lyubomirsky; King ve Deiner, 2005). Sonuç olarak mevcut araştırmadaki "Sence mutluluk nedir?" sorusuna ilişkin elde edilen bulguların alanyazındaki araştırma sonuçları ve kuramsal alanyazın tarafından desteklendiği ifade edilebilir.

Araştırmada çocuklara "Hangi durumlarda mutlu olursun/seni mutlu eden şeyler nelerdir?" şeklinde bir soru yöneltilmiştir. Bu soruya verilen cevaplara bakıldığında çocukların en çok aile ile vakit geçirmek, hediye almak, oyun oynamak, gezmek, başarı elde etmek gibi durumlardan mutlu oldukları sonucuna ulaşılmıştır. Alanyazında yapılan benzer bir çalışmada (Ocak-Karabay ve Güzeldere-Aydın, 2017) çocuklara kendilerini en çok mutlu eden durumların neler olduğu sorulmuş ve çocukların maddi kazanç, aile ile birlikte olmak, hediye almak, eğitim görmek gibi cevaplar verdikleri belirtilmiştir. Hong, Kim ve Jeun (2016) çocukların mutluluk kavramının ilişkin algılarını inceledikleri nitel araştırmalarında, çocukların en çok yemek yemek, okula gitmek, oyun oynamak ve kitap okumak gibi faaliyetlerden mutlu olduklarını saptamışlardır. Yine yapılan başka bir çalışmada (Hong, Ra ve Jang, 2015) çocukların hediye almak, sevdikleriyle bir arada olmak, gezmek, yemek yemek, başarı elde etmek gibi durumlardan mutlu olduklarını sonucuna ulaşılmıştır. Alanyazında bulunan diğer araştırmalar da benzer sonuçlar rapor etmektedir (Hwang, Kim ve Tak, 2013; O’Rourke, 2010; O'Farrelly, Booth, Tatlow-Golden, Barker, 2020). Mevcut araştırma bulgusu ve alanyazındaki araştırma sonuçları birlikte değerlendirildiğinde çocukların sadece maddi doyumlara değer vermedikleri, aynı oranda aile ile birlikte olmak, arkadaşlarla zaman geçirmek gibi ilişkisel ve manevi doyumlara da önem verdikleri söylenebilir. Büyükkucak'ın (2014) çocuklara alınan pahalı hediyeler yerine onlarla geçirilen nitelikli zamanın, çocuklar için daha değerli olduğunu ifade etmesi bu görüşü destekler niteliktedir. Çünkü maddi şeyler mutluluğun bir parçası olarak kabul edilmesine rağmen hedonik adaptasyonun etkisinden dolayı bu unsurların mutluluğu belirli bir sınırın üstüne çıkaramadığı ifade edilmektedir (Fatton vd., 2009; Lyubomirsky, 2008). Bundan dolayı kuramsal alanyazında çocukların maddi doyumlarının desteklenmesinin yanı sıra manevi doyumlar elde edecekleri yaşantıların sunulmasının uzun süreli ve kalıcı mutluluklar elde etmeleri üzerinde daha etkili olacağı belirtilmektedir (Seligman, 2002). Çünkü çocukların aileleriyle birlikte geçirmiş oldukları tatmin edici ve destekleyici ilişkisel yaşantılar ile pozitif aile tutumlarının, çocukların mutluluk düzeylerinin yükselmesine daha fazla katk1 sağlayacağı ifade edilmektedir (Lansdown, 2005; Miller, 2009; Sabolova, Birdsey, Hamilton ve Cousins, 2020; Thoilliez, 2011). Mevcut araştırmada "hangi durumlarda mutlu olursun/seni mutlu eden şeyler nelerdir?" soruna ilişkin elde edilen bulguların alanyazındaki araştırmaların sonuçları ve kuramsal alanyazındaki ifade edilen görüşlerle tutarlı olduğu söylenebilir. Diğer bir ifadeyle çocukların kendilerini mutlu eden durumlar içerisinde ilişkisel ve manevi doyumlara önem verdikleri ve erken çocukluk döneminde itibaren yakınsak gelişim alanında 
bulunan kişiler tarafindan ilişkisel olarak desteklenmelerinin, mutluluk düzeylerine önemli katkılar sağlayacağı söylenebilir. Ayrıca araştırmada bazı çocukların maddi şeylerden (hediye almak, alışverişi yapmak, bir şeyler yemek), bazı çocukların ise manevi şeylerden (aile ve arkadaşları vakit geçirmek gibi) mutlu oldukları görüşmüştür.

Araştırmada çocuklara "Yanınızda olmasından mutlu olduğunuz veya seni mutlu eden kişiler kimlerdir?" sorusu yönetilmiştir. Elde edilen bulguya göre çocuklar en çok baba, anne, arkadaş, kardeş, akrabalar, büyükbaba ve büyükanne gibi kișilerin yanlarında olmasından mutlu olduklarını belirtmişlerdir. Alanyazında araştırmanın bu bulgusunu destekleyen çalışmalar bulunmaktadır. McAuley'in (2019) çeşitli etnik köken ve kültürden olan on bir yaşındaki çocukların mutluluk kavramı ile algılarını değerlendirdiği araştırmasında çocukların anne, baba, yakın arkadaş ve aile büyükleri ile bir arada olmaktan mutlu oldukları sonucuna ulaşmışıı. Yine benzer şekilde yapılan başka bir araștırmada çocuklara kendilerini mutlu ede kişilerin kimler olduğu sorulmuş ve sırasıyla anne, baba ve kardeş şeklinde cevaplar alınmıştır (Ocak-Karabay ve Güzeldere-Aydın, 2017). Bir diğer araştırmada (Sabalova vd., 2020) çocukların ebeveynlerinin ve arkadaşlarının yanında bulunmaktan dolayı mutlu olduklarını sonucuna ulaşılmıştır. Alanyazında benzer sonuçlara ulaşan başka çalışmalar da bulunmaktadır (Chaplin, 2009; Ünüvar vd., 2015). Elde edilen mevcut araştırma bulgusuna göre çocukların kendilerini en çok aile fertlerinin yanında, ardından arkadaşlarının yanında olmaktan dolayı mutlu hissettikleri görülmektedir. Bu bulgunun kuramsal alanyazın incelendiğinde beklenen bir sonuç olduğu düşünülebilir. Çünkü Vygotsky $(1976,1978)$ Yakınsak Gelişim Alanı Kuram'ında çocukların sosyal çevrelerinin onların bütün gelişim alanları üzerinde büyük bir etkisinin olduğunu ifade etmektedir. Ayrıca Bronfenbrenner (1994) geliştirmiş olduğu Ekololojik Sistem Kuramı'nda çocuğun gelişimi üzerinde etkili olan faktörleri yakından uzağa olacak şekilde çeşitli katmanlara (mikrosistem, mezosistem, egzosistem ve makrosistem) ayırmıştır. Çocuğun gelişimi üzerinde birinci derecede etkili olan faktörlerin bulunduğu mikrosistem katmanında aile, arkadaş, akrabalık bağları ve okul gibi faktörler yer almaktadır (Bronfenbrenner, 1994). Bundan dolayı çocukların yanlarında olmalarından dolayı mutlu oldukları kişilere ilişkin vermiş oldukları cevapların kuramsal alanyazınla da örtüştüğü söylenebilir. Ayrıca çocukların yanlarında olmasından mutlu oldukları kişi sıralamasında arkadaş cevabının anne ve baba cevaplarından sonra en çok tercih edilen cevap olduğu görülmüştür. Kardeş, akrabalar, büyükbaba ve büyükanne gibi yakın aile fertlerinin tercih sıraları arkadaş cevabından sonra gelmektedir. Bu duruma ilkokul çağında bulunan çocukların arkadaşlık ilişkilerine verdikleri önemden dolayı böyle bir sonucun ortaya çıktığı düşünülebilir.

Araştırmada çocukların mutlulukla ilgili metaforik algıları incelenmiş ve çocukların üretmiş oldukları metaforlar Deiner ver arkadaşları (1999) tarafindan geliştirilen öznel iyi oluş kavramı göz önüne alınarak temalandırılmıştır. Bundan nedenle oluşturulan temalara yaşam doyumu, olumlu duygular ve olumsuz duygular başlıkları verilmiştir. Yapılan içerik analizi sonucunda çocukların öznel iyi oluş kavramının yaşam doyumu bileşeni ile ilgili aile, huzur, kitap, insan, hayat gibi metaforlar ürettikleri görülmüştür. Bu sonuçlar çocukların mutluluğu yaşamlarında sürekli yer almasını istedikleri bir duygu olarak değerlendirdikleri şeklinde yorumlanabilir. Diğer açıdan mutluluğu manevi ve iliş̧isel faktörlerle de eşleştirdikleri ifade edilebilir. Fakat alanyazında çocukların mutluluklarıyla ilgili metaforik algılarını inceleyen herhangi bir çalışmaya rastlanmamış ve bu bölümdeki bulgular benzer çalışmaların sonuçları ile tartışılmaya çalışılmıştır. Sargeant (2010) İngiltere ve Avusturalya'daki 7-11 yaş arası çocuklarla yapmış olduğu araştırmada çocuklara "Mutlu olmak için nelere ihtiyacınız var?" şeklinde bir soru yöneltmiş ve her iki gruptan da manevi (başarılı olmak, okumak) ve ilişkisel (aile ve arkadaşlarla zaman geçirmek) yönde gelen cevapların, maddi yönde gelen cevaplardan (telefon sahibi olmak, çikolata yemek) daha fazla olduğu sonucuna ulaşmıştır. Giacomoni, Souza ve Hutz (2014) 5-12 yaş arasındaki Portekizli çocuklarla yapmış oldukları nitel araştırmalarında çocukların mutluluk kavramları içerisinde arkadaşlarıyla birlikte olmak, ailesiyle vakit geçirmek, okula gitmek gibi unsurların olduğunu tespit etmişlerdir. Mevcut araştırma bulgusu ve alanyazındaki sınırlı sayıda yapılan araştırmanın sonuçları birlikte değerlendirildiğinde çocukların mutluluk düzeyleri üzerinde maddi faktörlerin yanı sıra manevi ve ilişkisel faktörlerinde oldukça etkili olduğuna söylenebilir. Alanyazındaki bazı araştırmaların da benzer sonuçlar rapor ettikleri görülmektedir (Hong, Ra ve Jang, 2015; Hong, Kim ve Jeun, 2016). Diğer açıdan mevcut araştırma bulgusunun kuramsal alanyazın tarafında da desteklendiği ifade edilebilir. Çünkü mutluluk kavramına açıklama getiren kuramsal teorilerinde doyum sağlayıcı sağlıklı ilişkilerin, bireylerin mutluluk 
seviyelerine olumlu katkılar sağladığı belirtilmektedir (Ryff, 1989; Seligman, 2012). Ayrıca çocukların aileleri tarafından sevilmesi, değer verilmesi ve onlarla sağlıklı ilişki kurmasının, çocukların mutluluk düzeyleriyle doğrudan ilişkili olduğu ifade edilmektedir (Park ve Lee, 2013). Diğer açıdan Huebner ve Gilman (2002) çocukların yaşam doyumları üzerinde okul, aile, arkadaş, çevre ve benlik olmak üzere beş temel alanın etkili olduğunu ifade etmiştir. Mevcut araştırmada çocukların öznel iyi oluş kavramının yaşam doyumu bileşenine ilişkin üretmiş oldukları metaforlar incelendiğinde, bunların Huebner ve Gilman'ın (2002) yukarıdaki açıklamaları ile örtüştüğü ifade edilebilir. Sonuç olarak elde edilen araştırma bulgusunun alanyazındaki araştırmalar ve kuramsal alanyazın tarafından desteklendiği ve çocukların yaşam doyumları üzerinde etkili olan faktörlerin mutluluk düzeylerini de etkileyeceği düşünülebilir.

Çocukların mutlulukla ilgili olumlu duygular teması altında üretmiş oldukları metaforlar incelendiğinde çiçek, pamuk, şeker, su, gülen yüz, deniz, uçmak, sevgi, hediye, kuş, pasta, bulut, beyaz balon, eğlence gibi metaforlar ürettikleri görülmüştür. Ulaşılan bu sonuçlara bakıldığı zaman çocukların mutluluğu olumlu durum ve yaşantılarla ilişkilendirdikleri görülmektedir. Alanyazıda benzer sonuçlara ulaşan çalışmalar bulunmaktadır. Örneğin; Hong, Kim ve Jeun (2016) tarafindan yapılan bir araştırmada çocukların mutluluğu yemek yemek, oyun oynamak, eğlenmek şeklinde kendilerinde olumlu duygular uyandıran durumlarla ilişkilendirdiklerini rapor etmişlerdir. Çocukların mutluluğu nasıl kavramsallaştırdıkları üzerine yapılan nitel bir araştırmada (Fattore, Mason ve Watson, 2009), çocukların mutluluk kavramıyla güvende olmak, başkalarının kendisine iyi davranması, heyecan duymak, sakinlik gibi olumlu yaşantılar arasında ilişki kurdukları sonuçlarına ulaşılmıştır. Alanyazında benzer sonuçları rapor eden başka çalışmalar da bulunmaktadır (Hwang, Kim ve Tak, 2013; Hong, Ra ve Jang, 2015; Thoilliez, 2011). Aynı zamanda bu sonuçlar Deiner ve arkadaşlarının (1999) öznel iyi oluş tanımıyla uyuşmaktadır. Çünkü Deiner ve arkadaşları (1999) bireylerin yaşamış oldukları olumlu yaşantı ve duyguların sıklık düzeyinin öznel iyi oluş düzeylerinin artmasında etkili olduğunu söylemektedirler. Bu açıklama ve mevcut araştırma bulgusu bir arada değerlendirildiği zaman çocukların mutluluk kavramını olumlu yaşantılar ve duygularla ilişkilendirmelerinin beklenen bir sonuç olduğu söylenebilir.

Araştırmanın son bulgusuna bakıldığı zaman sadece üç çocuğun kurşun kalem, hayal ve rüzgâr olmak üzere mutlulukla ilgili olumsuz metaforlar ürettikleri görülmüştür. $\mathrm{Bu}$ çocukların mutluğu çabuk geçen ve uzun süreli olmayan bir duygu olarak nitelendirdikleri söylenebilir. Alanyazında bu yönde araştırma bulgusu rapor eden herhangi bir araştırmaya rastlanmamıştır. Fakat alanyazında bazı bireylerin mutluluğa ilgili olumsuz bir bakış açısı geliştirebildikleri ve mutluluğa ilişkin bir korku taşıdıkları ifade edilmektedir (Jashanloo, 2013). Bu korkunun sebebi olarak da bireylerin mutluluk sonrasında kendilerini acı ve olumsuz şeylerin beklediğine ilişkin bir inanca sahip olmalarının neden olduğu belirtilmektedir (Bryant ve Veroff, 2007). Mevcut araştırmadaki çocukların da mutlulukla ilgili olumsuz bir algıya sahip olmaları üzerinde böyle bir olumsuz inanca sahip olmaları etkili olmuş olabilir.

Sonuç olarak, çocukların dünyasında mutluluk kavramının önemli bir yeri olduğu görülmüştür. Araştırmanın bulgularına bakıldığı zaman çocukların mutluluk kavramları içeresinde sadece maddi doyumların olmadığını aynı zamanda ilişkisel ve manevi doyumlara (aile ile birlikte olmak, sevilmek, sevmek vb.) da önem verdikleri ortaya çıkmıştır. Bu sonuçlar çocuklarla sürekli ilişki içerisinde bulunan aileler, öğretmenler veya bakım veren herkes tarafindan önemle üzerinde durulması gereken bir bulgudur. Çünkü çocuklara sadece maddi imkânların sunulması onlarda geçici bir mutluluk elde etmelerine neden olmaktadır. Bundan dolayı araştırmacılar çocukların mutluluk duygularının kalıcı olabilmesi için onlarla kurulan sağlıklı ve kaliteli sosyal ilişkilerin önemine vurgu yapmaktadırlar (Park ve Lee, 2013; Park ve Wang, 2019; Ryff, 1989; Seligman, 2012; Sabolova vd., 2020).

Alanyazın incelendiğinde çocukların mutluluklarını inceleyen sınırlı sayıda araştırmanı olduğu göze çarpmakta ve mutlulukla ilgili yapılan araştırmaların genellikle genç ve yetişkin bireyler üzerinde yapıldığı görülmektedir. Yapılan bu araştırma sadece bir ilde bulunan bir ilkokuldaki dördüncü sınıf öğrencileri üzerinde gerçekleştirilmiştir. Bundan sonra yapılacak başka bir çalışmada daha geniş bir örneklem grubu belirlenerek daha genellenebilir araştırma sonuçlarına ulaşılabilir. Diğer açıdan araştırma bulguları çocukların aile ve sosyal ilişkilerine oldukça önem verdikleri ve bunların mutluluk 
düzeyleri üzerinde etkili olduğu sonucuna ulaşılmıştır. İleride yapılacak olan başka bir çalışmada ebeveylerin mutlulukla ilgili görüşleri ile çocuklarının mutluluk düzeylerini arttırmak için neler yaptıklarını değerlendiren nitel bir çalışma gerçekleştirilebilir.

Eğitim sisteminin en önemli girdisini ve çıktısını çocuklar oluşturmaktadır. Eğitim süreçleri içerisinde bilişsel, fiziksel ve donanımsal faktörlere çok fazla dikkat edilmesine rağmen çocukların psikolojik ve duygusal gelişim alanları ihmal edilebilmektedir. Fakat çocuklar içinde bulundukları durumların ve yaşam koşullarının niteliğini/kalitesini değerlendirdikleri bir sisteme sahiptirler. $\mathrm{Bu}$ değerlendirme sistemi ise bireylerin herhangi olaydan veya durumdan hoşnut olup olmadıklarını belirttikleri bir kavram olan mutluluk kavramıyla somutlaştırılmaktadır. Araştırma sonuçları mutluluğun çocukların için ne kadar önemli olduğunu ortaya koymaktadır. Bu nedenle çocukların okul ortamlarında iyi oluşlarını destekleyecek faaliyetler ve çalışmalar gerçekleştirilerek onların mutluluk düzeylerinin artmasına katkılar sağlanmalıdır. Hatta ilkokul eğitim ve öğretim müfredatına çocukların pozitif kiş̧ilik özelliklerini destekleyecek derslerin ve etkinliklerin eklenmesinin onların bilişsel, duyuşsal ve davranışsal olarak daha sağlıklı bir gelişim süreci geçirmelerine katkı sağlayabileceği düşünülmektedir. 


\section{Kaynakça}

Amundson, N. E. (2011). Active engagement and the use of metaphors in employment counseling. Journal of Employment Counseling, 48(4), 182-185.

Alpay A. ve Eryılmaz, A. (2011). Lise öğrencilerinin öznel iyi oluşları ve okul tükenmişliği arasındaki ilişkiler . International Online Journal of Educational Sciences, 3(1), 181-199

Arık, İ. A. (1998). Psikolojide bilimsel yöntem. Ankara: Çantay Kitabevi

Balcı, A. (2018). Sosyal bilimlerde araştırma yöntem, teknik ve ilkeler. Ankara: Pegem Yayıncılık.

Ben-Arieh, A. (2006). Is the study of the "State of Our Children" changing? Revisiting after five years. Children and Youth Services Review, 28(7), 799-811.

Bronfenbrenner, U. (1994). Ecological models of human development. In International Encyclopedia of Education (2nd ed.). England:Oxford Press.

Büyükkucak, M. (2014). Hediyeleri değil, birlikte geçirdiğiniz zamanı hatırlarlar!. http://www.milliyet.com.tr/hediyeleri-degil--birlikte-pembenar-detay-cocuk-1622854/ (May1s 2019 tarihinde internetten alınmıştır).

Bryant, F. B. ve Veroff, J. (2007). Savoring: A new model of positive experience. Mahwah, NJ: Lawrence Erlbaum.

Bird, J. M. ve Markle, R. S. (2012). Subjective well-being in school environments: promoting positive youth development through evidence-based assessment and intervention. American Journal of Orthopsychiatry, 82, 61-66.

Chaplin, L. N. (2009). Please may I have a bike? Better yet, may I have a hug? An examination of children's and adolescents' happiness. Journal of Happiness studies, 10(5), 541-562.

Carr, A.(2016). Pozitif psikoloji. (Çev. Şendilek, Ü.). İstanbul: Kaknüs Yayınlar

Diener, E. (1984). Subjective well-being. Psychological Bulletin, 95, 542-575.

Diener, E., Suh, E. M., Lucas, R. E. and Smith, H. L. (1999). Subjective well-being: Three decades of progress. Psychological Bulletin, 125(2), 276.

Diener, E. and Lucas, R. E. (1999). 11 personality and subjective well-being. Well-being: Foundations of hedonic psychology. Russell: Sage Foundation.

Diener, E. (2000). Subjective well-being: The science of happiness and a proposal for a national index. American Psychologist, 55 (1), 34-43.

Diener, E. ve Seligman, M. E. P., (2002). Very Happy People. Psychological Science, 13(1), 81-84.

Diener, M. L. ve Lucas, R.E. (2004). Adults' desires for children's emotions across 48 countries: Associationwith individual and national characteristics. Journal of Cross-Cultural Psychology, $35,525-547$.

Doğan, T. (2013). Beş faktör kişilik özellikleri ve öznel iyi oluş. Doğuş Üniversitesi Dergisi, 14(1), 5664.

Demiriz, S. ve Ulutaş, İ. (2016). Çocuklar ne kadar mutlu. Bazı değişkenlere göre incelenmesi. Adnan Menderes Üniversitesi Ë̆itim Fakültesi Ĕ̈itim Bilimleri Dergisi, , 7(1), 16-24.

Eisenhart, M. A. and Howe, K. R. (1992). Validity in educational research. In M. LeCompte, W. Millroy, ve J. Preissle (Eds.), The handbook of qualitative research in education. (pp. 642680). San Diego: Academic Press.

Engels, N., Aelterman, A., Petegem, K. V. ve Schepens, A. (2004). Factors which influence the wellbeing of pupils in Flemish secondary schools. Educational Studies, 30, 127-143.

Fattore, T., Mason, J. ve Watson, E. (2009). When children are asked about their well-being: Towards a framework for guiding policy. Child Indicators Research, 2(1), 57-77.

Giacomoni, C. H., Souza, L. D. ve Hutz, C. S. (2014). A visão das crianças sobre a felicidade. Psicologia Escolar e Educacional, 18(1), 143-150.

Huebner, E. S. ve Gilman, R. (2002). An introduction to the multidimensional students' life satisfaction scale. Social Indicators Research, 60(1-3), 115-122.

Heubner, E. S., Suldo, S. M., Valois, R. R., Darne, J. W. ve Zullig, K. (2004). Brief multidimensional students' life satisfaction scale: Sex, race, and grade effects for high school sample. Psychological Reports, 94, 351-356.

Hong, Y., Ra, Y. ve Jang, H. (2015). A study on young children's perceptions and experiences of happiness. Asia-Pacific Journal of Research in Early Childhood Education, 9(1), 39-64. 
Hong, Y., Kim, H. ve Jeun, W. (2016). A study on what makes young children happy. Asia-Pacific Journal of Research in Early Childhood Education, 10(2), 47-70.

Honig, A. S. ve Brophy, H. E. (1996). Talking with your baby: family as the first school. Syracuse: Syracuse University Press.

Hwang, H., Kim, M. ve Tak, J. (2013). A study of five-year-old children`s happiness as measured by the cognition of being happy and the condition of happiness. The Journal of Eco-Early Childhood Education, 12(4), 93-122.

Jensen, D. (2006). Metaphors as a bridge to understanding educational and social contexts. International Journal of Qualitative Methods, 5(1), 36-54.

Joshanloo, M. (2013). The influence of fear of happiness beliefs on responses to the satisfaction with life scale. Personality and Individual Differences, 54, 647-651.

Kantarcıoğlu, S. (1998). Anaokulunda eğitim. Öğretmen kitaplarl dizisi. İstanbul: MEB Yayınları.

Karabay, Ş. O. ve Aydın, D. G. (2017). Farklı geçmiş yaşantılardan gelen çocukların mutluluk ve gelecek ile ilgili görüşleri. Illkögretim Online, 16(4), 1816-1828.

Konu, A. I., Lintonen, T. P. and Autio, V. J. (2002). Evaluation of well-being in schools-a multilevel analysis of general subjective well-being. School Effectiveness and School Improvement, 13(2), 187-200.

Lansdown, G. (2005). Can you hear me? The right of young children to participate in decisions affecting them. Working paper 36. The Netherlands: Bernard Van Leer Foundation.

Lyubomirsky, S., King, L. ve Diener, E. (2005). The benefits of frequent positive affect: Does happiness lead to success? Psychological Bulletin. (131), 803-855.

Lyubomirsky, S. (2001). Why are some people happier than others? The role of cognitive and motivational processes in well-being. American Psychologist. (56), 239-249.

Lyubomirsky, S. (2008). The how of happiness: A scientific approach to getting the life you want. Penguin.

Lu, L. (1995). The relationship between subjective well-being and psychosocial variables in Taiwan. The Journal of Social Psychology. (135), 351-357.

McAuley, C. (2019). Exploring eleven year old children's understanding of well-being using well-bein maps: Commonalities and divergences across areas of varying levels of deprivation and ethnic diversity in an English Qualitative Study. Children and Youth Services Review, 97, 22-29.

Myers, D. G. ve Diener, E. (1995). Who is happy?. Psychological Science, 6(1), 10-19.

Maxwell, J. (1992). Understanding and validity in qualitative research. Harvard Educational Review, 62(3), 279-301.

Merriam, S. B. (2009). Qualitative research: A guide to design and interpretation. San Francisco: Jos sey-Bass.

Morrow, S. L. (2005). Quality and trustworthiness in qualitative research in counseling psychology. Journal of counseling psychology, 52(2), 250-260.

Mahon, N. E. ve Yarcheski, A. (2002). Alternative theories of happiness in early adolescents. Clinical Nursing Research, 11, 306-323.

Miller, J. (2009). Never too young. how young children can take responsibility and make decisions. London: Save the Children Press.

O'Farrelly, C., Booth, A., Tatlow-Golden, M. ve Barker, B. (2020). Reconstructing readiness: Young children's priorities for their early school adjustment. Early Childhood Research Quarterly, 50, 3-16.

O'Rourke, J. ve Cooper, M. (2010). Lucky to be happy: A study of happiness in Australian primary students. Australian Journal of Educational and Developmental Psychology, 10, 94-107.

Park, N. ve Peterson, C. (2006). Character strengths and happiness among young children: content analysis of parental descriptions. Journal of Happiness Studies, 7(3), 323-341.

Park, S. ve Lee, M. (2013). Social recognition as a determinant of happiness. Society and Theory, 23, 361-391.

Park, K. ve Wang, S. (2019). Youth activities and children's subjective well-being in korea. Journal of Happiness Studies, 20(7), 2351-2365.

Richter, A. Gilbert, P. ve McEwan, K. (2009). Development of an early memories of warmth and safeness scale and its relationship to psychopathology. Psychology and Psychotherapy: Theory, Research and Practice, (82), 171-184. 
Ryff, C. D. (1989). Happiness is everything, or is it? Explorations on the meaning of psychological well-being. Journal of Personality and Social Psychology, 57(6), 1069-1081.

Sargeant, J. (2010). The altruism of pre-adolescent children's perspectives on 'worry'and 'happiness' in Australia and England. Childhood, 17(3), 411-425.

Sabolova, K. Birdsey, N., Stuart-Hamilton, I. ve Cousins, A. L. (2020). A cross-cultural exploration of children's perceptions of wellbeing: Understanding protective and risk factors. Children and Youth Services Review, 110, 1-10.

Seligman, M. E. P. ve Csikszentmihalyi, M. (2000). Positive psychology: An introduction. American Psychologist, 55(1), 5-14.

Seligman, M. (2002). Authentic happiness: using the new positive psychology to realize your potential for lasting fulfillment. New York, NY: Free Press

Seligman, M. E. P. Ernst, R. M., Gillham, J., Reivich, K., and Linkins, M. (2009). Positive education: Positive psychology and classroom interventions. Oxford Review of Education, 35(3), 293 311.

Seligman, M. E. (2012). Flourish: A visionary new understanding of happiness and well-being. Free Press: Simonschuster

Simon, J. L. (1985). Basic research methods in social science. (4. Baskı). New York: Random House.

Telef, B. B. (2014). School children's happiness inventory: The validity and reliability study. International Online Journal of Educational Sciences, 6(1), 130-143.

Thoilliez, B. (2011). How to grow up happy: An exploratory study on the meaning of happiness from children's voices. Child Indicators Research, 4(2), 323-351.

Türk Dil Kurumu (TDK) (2020). Türk Dil Kurumu Sözlüğü. Türk Dil Kurumu web sitesi. http://www.tdk.gov.tr.

Tobin, D. (2014). Children's right to be heard: Exploring children's perceptions of happiness and factors contributing to happiness in the pre-school environment. Masters dissertation. Institute of Technology, Technological University Dublin.

Ünüvar, P., Çalışandemir, F., Tagay, Ö. ve Amini, F. (2015). Preschool children's perception of happiness (Turkey and Afghanistan Sample). Mehmet Akif Ersoy Üniversitesi Eğitim Fakültesi Dergisi, 34, 1-22.

Uusitalo-Malmivaara, L. (2012). Global and school-related happiness in Finnish children. Journal of Happiness Studies, 13(4), 601-619.

Yucel, D. ve Yuan, A. V. (2015). Do siblings matter? The effect of siblings on socio-emotional development and educational aspirations among early adolescents. Child Indicators Research, 8(3), 671-697.

Yıldırım, A. ve Şimşek, H. (2006). Sosyal bilimlerde nitel araştırma yöntemleri. Ankara: Seçkin Yayıncilik.

Yıldırım, A. ve Şimşek, H. (2013). Sosyal bilimlerde nitel araştırma yöntemleri (9. Baskl). Ankara: Seçkin Yayıncilık.

Vygotsky, L. S. (1976). Play and its role in the mental of the child. Soviet Psychology, 5(3), 6-18.

Vygotsky, L. S. (1978). Interaction between learning and development. Readings on the Development of Children, 23(3), 34-41.

Waver, R. D., Habibov, N. ve Fan, L. (2010). Devolution and the poverty reduction effectiveness of Canada's provincial social welfare programs: Results from a time-series investigation of a Canadian national survey. Journal of Policy Practice, 9(2), 80-95. 


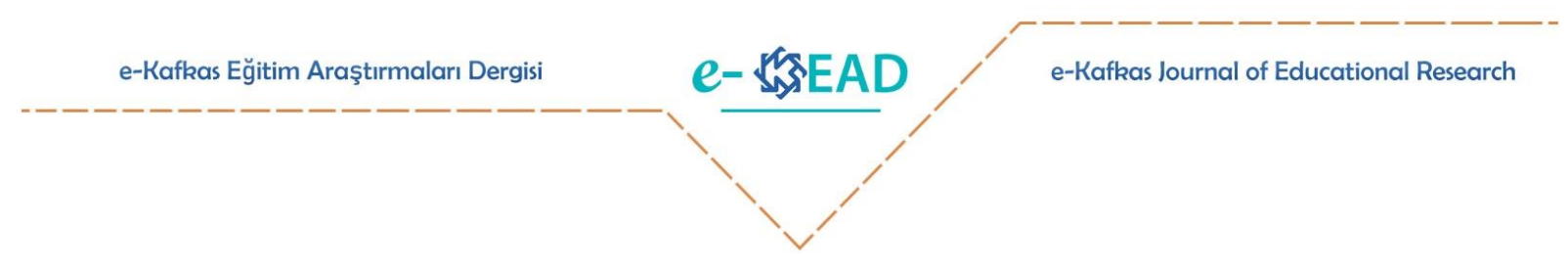

\section{Evaluation of Primary School Fourth Grade Students' Thoughts About Happiness: A Qualitative Study}

\section{Faruk Caner YAM}

To cite this article: Yam, F.C. (2020). Evaluation of primary school fourth grade students' thoughts about happiness: A qualitative study.e- Kafkas Eğitim Araştırmalart Dergisi, $7, \quad 262-281$. doi:10.30900/kafkasegt.764370

\section{Introduction}

The most important input and output of the education system are children. Although cognitive, physical and hardware factors are considered within the educational processes, the spiritual and emotional worlds of children can be neglected. Children have a system in which they evaluate whether they are satisfied with their situation. In this case, the concept of happiness is an important concept. Happiness is defined as a person's cognitive and emotional evaluation (Diener, 1984). On the other hand, positive psychology expresses happiness with the concept of subjective well-being. According to this approach, subjective well-being is often expressed as positive feelings, frequent negative feelings and high life satisfaction (Diener, 1984; Myers and Diener 1995).

Happiness is a psychological factor that plays an important role in preventing anxiety and stress from obstacles in the developmental process of the child (Lyubomirsky, 2001; Mahon and Yarcheski, 2002). Because the researchs show that the way in which interpret, evaluate and react to the events of the happy individuals is more constructive and healthy than those who are not happy (Lu, 1995; Lyubomirsky, King and Diener, 2005; Lyubomirsky, 2001).

In these days, when the sense of burnout, school dissatisfaction and the concept of unhappiness have reached the level of primary school, determining the perceptions of children about happiness and researching the factors affecting their happiness levels is an important issue in terms of supporting their development areas better. Considering that the concept of happiness affects the quality of life of individuals in all developmental periods, examining how this concept is perceived by children and how they affect their lives constitutes an important research area (Fattore, et al., 2009). In addition, although it is known that children have a perspective about happiness, it is stated that researchers have little use of their ideas on this subject and mostly try to evaluate children's perceptions of happiness based on their parents' opinions (Ben-Arieh, 2006; Hwang, Kim and Tak, 2013; Hong, Ra and Jang, 2015). Due to all these reasons explained above, it was aimed to examine what the primary school fourth grade students' opinions about happiness and contribute to the related literature.

\section{Method}

The research model, population-sample / study group, data collection tools, validity and reliability of data collection tools, data collection techniques, data analysis, limitations should be detailed. This research is a study of qualitative research in which fourth grade students' thoughts about happiness are determined. The aim in qualitative research is to examine the subject in depth (Creswell, 2014). In this study, metaphor method was used to reveal and evaluate the mental images of the children for happiness (Amundson, 2011; Jensen, 2006). The data of the study consisted of five open- 
ended questions which were determined to be appropriate for the purpose of the study. The theoretical knowledge about happiness (Diener, 1984; Myers and Diener 1995; Ryff, 1989; Seligman, 2012) and the researches about the happiness of children were examined in determining open-ended questions (Hong, Ra and Jang, 2015; Hong, Kim and Jeun, 2016; Ocak-Karabey and Güzeldere-Aydın, 2017; Ünüvar et al., 2015).

\section{Discussion, Conclusion and Recommendations}

According to the results of the study, the children described the concept of happiness as the most of joy, having fun, being loved, loving, being together with their loved ones. Studies in the literature support this finding (Ünüvar et al., 2015; Hong, Kim and Jeun, 2016; Tobin, 2014). From these answers, it was evaluated that children pointed out the elements of moral in the definitions of happiness. In other respect, the children stated that they felt most happy with their parents, siblings and relatives. These results are in line with the results of other studies (Giacomoni, Souza and Hutz, 2014; Hwang, Kim and Tak 2013). When we look at the answers given by the children, it can be said that they give more importance to the elements that provide sprituel satisfaction within the definitions of happiness than those that provide material satisfaction. In addition, it was observed that the children made mostly positive definitions about the concept of happiness. It can be said that the current research finding obtained overlaps with the theoretical structure developed regarding happiness. When the subjective well-being model of Deiner (1984), the PERMA model of Seligman (2012) and the psychological well-being model of Ryff (1989) are examined, it is seen that one of the components of these models are positive emotions. As a result, it can be stated that the findings obtained in the current research are supported by the results of other researches and theoretical literature.

According to another finding of the research, it was concluded that children are most happy with situations such as spending time with the family, receiving gifts, playing with friends, traveling, achieving success, eating and swimming. Some studies in the literature support this finding of the research. (Hwang, Kim and Tak 2013; Hong, Ra and Jang, 2015; Oen Rourke, 2011). In addition, the findings of the research indicated that children are satisfied with the spiritual satisfaction. Büyükkucak (2014) supports this finding by saying that the time spent with children instead of expensive gifts is more valuable for children. In the study children were asked who they were happy with. Because material things are accepted as a part of happiness, it is stated that due to hedonic adaptation, material elements cannot bring happiness above a certain limit (Fatton and et al., 2009; Lyubomirsky, 2008). Therefore, in the theoretical literature, it is said that supporting the material satisfaction of children, as well as providing environments where they will achieve spiritual satisfaction will be more effective on achieving long-term happiness (Seligman, 2002).

According to the results of the study, it was seen that the children were happy to be with their father, mother, friends, siblings, relatives, grandparents. There are other studies in the literature supporting these results (Chaplin, 2009; Unüvar et al., 2015; Sabalova et al., 2020). According to the current research finding, the children said that they felt most happy to be with their family members and friends. It can be thought that this finding is an expected result when the theoretical literature is examined. Because Vygotsky $(1976,1978)$ states that in the Convergent Development Field Theory, the social environment of children has a great influence on all their development areas. In addition, Bronfenbrenner (1994) has divided the factors that affect the development of the child into several layers (microsystem, mesosystem, ecosystem and macrosystem) in the Ecology System Theory he developed. There are factors such as family, friends, kinship ties and school in the microsystem layer, where there are firstly influential factors on the child's development (Bronfenbrenner, 1994). For this reason, it can be said that the result of the current research on the people they are happy to be with the children is also compatible with the theoretical literature.

In this study, metaphors of children about happiness were examined. The metaphors obtained are themed according to the components of subjective well-being defined by Diener et al. (1999). As a result of the analysis, they produced metaphors such as family, peace, books and human about the life satisfaction theme of happiness. In the literature, there are studies that obtained results similar to this finding of the research. (Hong, Ra and Jang, 2015; Hong, Kim and Jeun, 2016). Therefore, the feeling 
that children are loved, valued and have a healthy relationship with their families is closely related to their feelings of happiness. (Park and Lee, 2013).

When the positive emotions component of children's happiness metaphors are examined, it is seen that children produce metaphors such as flower, cotton, sugar, water, smiling face, sea and flying. These results lead to the conclusion that children describe happiness as a good feeling. All these results are in line with the results of a limited number of studies in the literature. (Hwang, Kim and Tak, 2013; Hong, Ra and Jang, 2015). Another finding of the study was that only three children produced negative metaphors such as pencil, dream and wind about happiness. It can be thought that these children do not see happiness as a long-term feeling. No research has been found in the literature that reaches such a result. However, it is stated in the literature that some individuals can develop a negative view of happiness and have a fear of happiness (Jashanloo, 2013). The reason for this is explained as the belief that negative things such as pain and grief await them after happiness (Bryant and Veroff, 2007). In the current research, it may have been effective for children to experience fear of happiness in producing negative metaphors about happiness. 